in particular, it will act as an agent for ASTEC in obtaining and supplying data in conducting or commissioning studies and in carrying out those liaison and other tasks both within and outside Government that it is favourably placed to undertake". As far as the Department was concerned, the demarcation lines in the highly competitive business of influencing the government are kept nicely fuzzy. All this, of course, may be water under the bridge when the Liberal Government's current review of ASTEC is publicised and implemented.

In support of its own advisory role, the Department has pursued its data collecting activities. The long-running Project SCORE (Survey and Comparison of Research Expenditure) first surveyed expenditure and manpower in Australian research and development for the financial year 1968-69; the results were published in 1972 and 1973. Project SCORE is now reported to be "well underway" on "two-yearly intervals" and using OECD bases for statistics "to be sure that Australian figures may be compared with overseas figures".

The day after the report's period of survey concluded, that is, July 1, 1975, the 555-strong Patent Office was removed from the Department and transferred to the Attorney-General's Department (more recently still it has found another home in Business and Consumer Affairs).

It is easy for outside observers (and most insiders, too) to be bamboozled by the dispersed nature of Australia's scientific organisation. This is not, however, an argument for centralised control, but for at least one government sponsored effort to document in assimilable form the standing and overall progress of science on a national scale. The Science Department's report cannot claim to do this, nor to be fair does it claim to do so. Yet, not many scientists in Australia are more than dimly aware of what is going on in fields outside their own speciality. The interested public and politicians find the task equally tough, although they are helped by some very informative programmes on $\mathrm{ABC}$ radio.

The only organisation in Australia which has had the drive and capacity to fill this information breach is the interim ASTEC, but it is still on ice while the government reviews its aims and operations. If, however, ASTEC is allowed by Prime Minister Malcolm Fraser to survive in anything like its form under Labor which would make public reporting central to its functions, then the prospects of the scientific community and general public alike catching and keeping up with the hare of Australian research are quite bright. $\mathrm{Or}$, is it a tortoise?

USSR

\section{Give and take}

April, traditionally an auspicious month for Soviet scientists with the announcement of the Lenin Prizes, has this year brought an ominous picture for those out of favour with the establishment: two dissident scientists on trial, continuing harassment and repression of refusniks, and Academician Andrei Sakharov briefly held with his wife in police custody. Vera Rich reports

THE recent "Omsk incident" involving Academician Sakharov marks a new development in the Soviet authorities' campaign against him-the loss of his personal immunity. It happened when Sakharov and his wife Yelena tried to attend the trial of Mustafa Dzhemilev, a young agronomist who has become the leader of the movement for the repatriation of the Crimean Tartars, deported en masse to Siberia in 1944.

"Political" trials in the Soviet Union are not normally open to the public, but Sakharov did sometimes manage to enter the courtroom as a friend of the accused-in the case of the mathematician, Dr R. I. Pimenov, in 1970, for example. By 1972, however, when Vladimir Bukovskii was on trial for having sent to the West detailed reports on Soviet misuse of psychiatry for political ends, Sakharov was no longer admitted, protesting instead outside the court. Now he and his wife have been prevented from doing even this.

According to Sakharov, who says two official TASS bulletins on the incident are false, plain-clothes KGB men prevented the friends and relatives of the accused from entering the courtroom, using "rude physical force", directed "in particular" at Sakharov and his wife. In an "immediate reaction" to the "mockery of the feelings of friends and relatives, the mockery of the law, the whole tragic circumstances of this case and other political cases in our country", Sakharov said he hit in the face "one or two KGB men" and a civil policeman who was acting on KGB orders. The Sakharovs were removed to police headquarters, where Sakharov made a statement claiming that the police were acting "on the side of the law-breakers". The next day, the Sakharovs tried once again to protest against the exclusion of the Dzhemilev family from the court, and again were taken to police headquarters.

Sakharov stresses that the civil police treated them "correctly", and says that earlier reports to the contrary were due to a bad telephone connection to Omsk. He denies vehemently that he created a disturbance in the courtroom, as TASS had claimed. This was quite impossible, he says, since "three ranks of KGB men" prevented them even getting near the court. He admits that the possibility of criminal charges against himself is "not excluded".

Sakharov's attempt to focus world attention on the Dzhemilev trial in Omsk, a city closed to foreign journalists, came at the same time as his friend and close associate in the human rights movement, physicist Andrei Tverdokhlebov, faced similar charges of anti-Soviet activity in Moscow. Sakharov felt that the location of this trial in the capital, and the fact that Tverdokhlebov's membership of the illicit Moscow group of Amnesty International makes him a well-known figure, would ensure publicity abroad, whereas the Dzhemilev trial might pass unnoticed without his presence. Tverdokhlebov was sentenced to 5 years' exile; Dzhemilev received $2 \frac{1}{2}$ years in a strict regime labour camp.

As for the general position of dissident scientists, this shows little sign of improving. The Kiev seminar for Jewish refusnik scientists, one of the many off-shoots of the original Voronel seminar in Moscow, and led by physicist Vladimir Kislik, has been shut down. Mark Azbel, who now runs the Voronel seminar, has once again been refused a visa for Israel. And Professor Veniamin Fain, one of the very few activists and refusniks to be allowed to continue in his academic career, has now been dismissed from his post at the Institute of Solid State Physics in Moscow.

Sakharov has meanwhile accepted an invitation to become a member of the executive committee of the Campaign Against Psychiatric Abuse (SAPA), the British section of the International Initiating Committee against Misuses of Psychiatry for Political Purposes. $\square$

\section{Sorry, for copyright reasons some images on this page may not be available online}

